\title{
PENINGKATAN KOMPETENSI PENGOLAHAN DATA SEDERHANA DENGAN MICROSOFT EXCEL 2013 PADA PKBM BINA BANGSA LARANGAN SELATAN KOTA TANGERANG
}

\author{
Yesi Puspita Dewi ${ }^{*}$, Wulandari ${ }^{1}$ \\ ${ }^{I}$ Sistem Informasi, Fakultas Teknologi Informasi,Universitas Budi Luhur \\ Jl. Ciledug Raya, Petukangan Utara, Jakarta Selatan 12260 \\ Email Penulis Korespondensi: yesi.puspitadewi@budiluhur.ac.id
}

\begin{abstract}
Abstrak
Pusat Kegiatan Belajar Masysrakat (PKBM) Bina Bangsa merupakan salah satu lembaga yang bergerak dalam bidang pendidikan nonformal yang beralamatkan di Larangan Selatan Kota Tangerang Provinsi Banten. Tujuan didirikan PKBM ini adalah membantu siswa putus sekolah dengan mengambil sekolah paket. Permasalahan lain yang terjadi yaitu lulusan PKBM masih bersifat kuantitas, belum dibarengi dengan kualitas. Siswa PKBM Bina Bangsa perlu menigkatkan kompetensi agar dapat bersaing dimasyarakat terutama dalam bidang komputer terutama pengolahan data sederhana menggunakan Microsoft Excel. Microsoft Excel sendiri sudah banyak digunakan dalam berbagai bidang pekerjaan dan perkantoran, sehingga kompetensi ini perlu ditingkatkan guna meningkatkan keterampilan siswa dalam mengolah data sederhana. Metode yang digunakan dalam pelatihan ini pertama Analisa yaitu dengan Analisa Situasi Peserta, Identifikasi Masalah, Menentukan Tujuan dan Rencana Pemecahan Masalah, Kedua implementasi yaitu pada saat pelaksanaan memberikan teori ke siswa dan dilakukan tanya jawab dan praktikum studi kasus, Ketiga Evaluasi yaitu memberikan post test ke siswa. Hasil dari post test yang di kerjakan siswa didapat nilai rata-rata yang dikombinasikan dengan parameter keberhasilan dan didapat nilai "A" yang berarti kompetensi kemampuan mengolah data sederhana menggunakan Microsoft Excel meningkat setelah dilakukan pelatihan kegiatan pengabdian masyarakat ini.
\end{abstract}

Kata kunci: Kompetensi siswa, Microsoft excel, Pelatihan komputer, Pengolahan data sederhana, PKBM

\begin{abstract}
Center for Community Learning Activities (PKBM) Bina Bangsa is one of the institutions engaged in the field of non-formal education which is addressing the South Larangan, Tangerang City, Banten Province. The purpose of this PKBM was to help students drop out of school by taking a package school. Another problem that occurs is that PKBM graduates are still quantity, not accompanied by quality. Bina Bangsa PKBM students need to improve their competence to compete in the community, especially in the field of computers, especially simple data processing using Microsoft Excel. Microsoft Excel itself has been widely used in various fields of work and offices, so this competency needs to be improved to improve student skills in processing simple data. The methods used in this training are firstly Analysis of Participant Situation Analysis, Problem Identification, Determining Goals and Problem-Solving Plans, Secondly, implementation, when the implementation of a theory is made to students and question and answer practicum and case study practicum, Third Evaluation is to provide a post-test to students. The results of the post-test conducted by students obtained an average value combined with the parameters of success and obtained the value of "A" which means that the competency of simple data processing skills using Microsoft Excel increases after this community service training is conducted.
\end{abstract}

Keywords: Computer training, Microsoft excel, PKBM, Simple data processing, Student Competencies 


\section{PENDAhULUAN}

Pusat Kegiatan Belajar Masyarakat atau biasa disebut dengan PKBM merupakan salah satu lembaga yang bergerak dalam bidang pendidikan. (Jalal \& D, 2001) menjelaskan, PKBM merupakan organisasi masyarakat yang menyelenggarakan pendidikan nonformal sebagai upaya pemecahan masalah yang terkait dengan masalah putus sekolah maupun masalah pengangguran. Pusat Kegiatan Belajar Masyarakat (PKBM) merupakan salah satu alternatif yang dapat dipilih dan dijadikan ajang pemberdayaan masyarakat.

Permasalahan yang dihadapi saat ini seiring berkembangnya jumlah PKBM namun tidak diikuti dengan meningkatnya jumlah masyarakat yang terlayani dan belum mengukir prestasi(Hardjono, Raharjo, \& Suminar, 2010), pertumbuhan PKBM masih bersifat kuantitas, belum dibarengi dengan kualitas.(Suminar, 2007).

Pusat Kegiatan Belajar Masyarakat (PKBM) Bina Bangsa memiliki siswa yang perlu kompetensi agar dapat bersaing dimasyarakat, sayangnya kompetensi dalam bidang komputer terutama pengolahan data sederhana menggunakan Microsoft Excel belum terpenuhi. Microsoft Excel banyak digunakan dalam berbagai bidang pekerjaan dan perkantoran, sehingga kompetensi ini perlu ditingkatkan.

Hal tersebut membuat tim pengabdian masyarakat tergerak untuk melaksanakan pelatihan dalam bidang TIK bersama dengan pihak PKBM Bina Bangsa selaku mitra guna meningkatkan kompetensi/kemampuan siswa dalam menggunakan aplikasi Microsoft Excel. Sebagaimana tertuang dalam (Indonesia, 2005) sebagai pendidik profesional dan ilmuwan yang mengemban tugas utama yaitu melakukan transformasi, melakukan pengembangan dan menyebarluaskan ilmu pengetahuan, teknologi, dan seni melalui pendidikan, penelitian, dan pengabdian kepada masyarakat.

Tujuan kegiatan ini adalah memberikan pembekalan softskill kepada siswa Pusat Kegiatan Belajar Masyarakat (PKBM) Bina Bangsa dengan aplikasi Microsoft Excel yang banyak digunakan dalam berbagai bidang pekerjaan dan perkantoran sehingga dapat beradaptasi dalam lingkungan kerja pada masa yang akan datang.

\section{METODE PELAKSANAAN}

\section{Waktu dan Tempat Pelaksanaan}

Kegiatan pengabdian masyarakat ini dilakukan pada tanggal 16 November 2019 di laboratorium komputer Universitas Budi Luhur, ruangan 14, pada hari sabtu pukul $09.00 \mathrm{~s} / \mathrm{d}$ 16.00 .

\section{Alat dan Bahan:}

Media yang digunakan pada kegian pengabdian masyarakat ini yaitu: Komputer yang terinstal Microsoft Excel, screen projector, panduan materi pelatihan, papan tulis dan spidol.

\section{Langkah Pelaksanaan}

Metode yang digunakan dalam kegiatan pengabdian masyarakat dibagi menjadi beberapa tahapan yang ditunjukan pada Gambar 1 ;

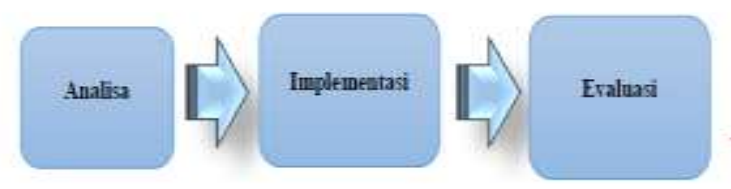

Gambar 1. Bagan Metode Pelaksanaan

Tabel 1 Tahapan Kegiatan pengabdian masyarakat

\begin{tabular}{|c|c|c|}
\hline No & Kegiatan & $\begin{array}{c}\text { Waktu } \\
\text { (Bulan dan } \\
\text { Minggu ke) }\end{array}$ \\
\hline 1 & $\begin{array}{l}\text { Konsultasi dengan pihak } \\
\text { PKBM;Analisa yaitu analisa } \\
\text { situasi peserta, Identifikasi } \\
\text { Masalah, Menentukan tujuan } \\
\text { dan rencana pemecahan } \\
\text { masalah. }\end{array}$ & $\begin{array}{l}\text { Oktober, } \\
\text { minggu ke- } \\
2 \mathrm{~s} / \mathrm{d} \\
\text { minggu ke- } \\
4\end{array}$ \\
\hline 2 & $\begin{array}{l}\text { Persiapan kegiatan; } \\
\text { penyewaan lab komputer, } \\
\text { fotocopy materi pelatihan }\end{array}$ & $\begin{array}{l}\text { November } \\
\text { minggu ke- } \\
1\end{array}$ \\
\hline 3 & $\begin{array}{l}\text { Pelaksanaan } \\
\text { kegiatan;implementasi }\end{array}$ & $\begin{array}{l}\text { November, } \\
\text { minggu ke- } \\
2\end{array}$ \\
\hline 4 & $\begin{array}{l}\text { Evaluasi, memberikan post } \\
\text { test ke peserta dan } \\
\text { mengevaluasi hasil }\end{array}$ & $\begin{array}{l}\text { November, } \\
\text { minggu ke- } \\
2\end{array}$ \\
\hline
\end{tabular}


Analisa

\section{Analisa Situasi Peserta}

Pengusul melakukan pertemuan dengan pihak PKBM Bina Bangsa untuk melakukan diskusi langsung mengenai salah satu tujuan satuan pendidikan di PKBM tersebut. Pengusul menganalisa target calon peserta berdasarkan tingkat kebutuhan serta tujuan pemanfaatan teknologi terkini dalam menghadapi permasalahan.

\section{Identifikasi Masalah}

Mengidentifikasi permasalahan yang dialami peserta yaitu kurangnya softskill, Microsoft Office khususnya Excel, selain itu belum menguasai penggunaan aplikasi Microsoft Excel dalam bidang statistik dan pengolahan data sederhana. Hal ini cukup krusial mengingat Microsoft Excel banyak digunakan dalam berbagai bidang pekerjaan dan perkantoran.

\section{Menentukan Tujuan}

Untuk mencapai tujuan yaitu memberikan pembekalan softskill kepada siswa, pengusul melakukan pelatihan berupa pemaparan teori kemudian praktikum yang diarahkan/dipandu oleh trainer dan siswa didamping 3 pendamping.

\section{Rencana Pemecahan Masalah}

Untuk mejawab permasalahan yang dihadapi, pengusul akan memandu peserta dalam praktikum langsung penggunaan Microsoft Excel dan memberikan simulasi dan contoh latihan soal seperti pekerjaan yang biasa dilakukan pada dunia kerja dan perkantoran.

\section{Implementasi}

Tahapan implementasi kegiatan pada pengabdian masyarakat ini yaitu:

a. Melakukan tanya jawab sebelum pelatihan dimulai untuk mengetahui sejauh mana pengetahuan peserta tentang Microsoft Excel.

b. Memberikan teori Microsoft Excel dasar, instruktur dan asisten instruktur memberikan teori terkait materi pelatihan. Materi disampaikan secara bergantian oleh instruktur dan asisten instruktur untuk masing- masing topik. c. Metode praktek untuk pelatihan Microsoft Excel ini dilakukan dengan cara: Instruktur memberikan penjelasan terkait dengan materi pelatihan dengan menggunakan alat peraga berupa komputer, kemudian peserta pelatihan didampingi oleh asisten instruktur dan asisten laboratorium. Bagi peserta yang ingin bertanya pada saat pelatihan berlangsung dapat langsung bertanya kepada instruktur. Apabila saat praktek peserta mengalami kesulitan maka asisten instruktur dan asisten laboratorium akan memberikan bantuan atas kesulitan yang dialami, agar tidak tertinggal dalam mengikuti materi pelatihan.

d. Melakkukan sesi tanya jawab dengan peserta didik dan memberikan post test sederhana sebagai bahan evaluasi keberhasilan kegiatan yang dilaksanakan.

\section{Evaluasi}

Tahapan evaluasi dilakukan berdasarkan hasil post test yang berikan kepada peserta untuk mengetahui sejauh mana pengetahuan peserta terhadap kegiatan. Selain itu pengusul juga akan mengevaluasi keberhasilan pelatihan yang diberikan berdasarkan keberhasilan penggunaan Microsoft Excel.

\section{HASIL DAN PEMBAHASAN}

Kegiatan pengabdian masyarakat yang dilakukan pada tanggal 16 November 2019 dihadiri oleh 30 siswa dari PKBM Bina Bangsa yang sedang mengambil sekolah paket. Dalam Kegiatan pengabdian masyarakat ini tim kegiatan pengabdian masyarakat dimana notabennya adalah dosen yang mengampu matakuliah dalam bidang TIK/Komputer memberikan pelatihan dan pendampingan kepada siswa PKBM selama pelatihan berlangsung. Pelatihan yang diberikan adalah mengolah data sederhana menggunakan Microsoft Excel.

Materi pelatihan pada kegiatan pengabdian masyarakat yaitu (a) Pengenalan dan input data pada Ms. Excel, (b) Membuat tabel, (c) Melakukan format cell (Melakukan copy dan memindahkan cell, menggabungkan cell, simbol mata uang), (d) Fungsi fungsi perhitungan (sum, count, average, max, min), (e) Melakukan format karakter (mid, left, right, len, upper). 
Kegiatan pengabdian masyarakat ditunjukan pada gambar 2, 3, 4,5 berikut ini:

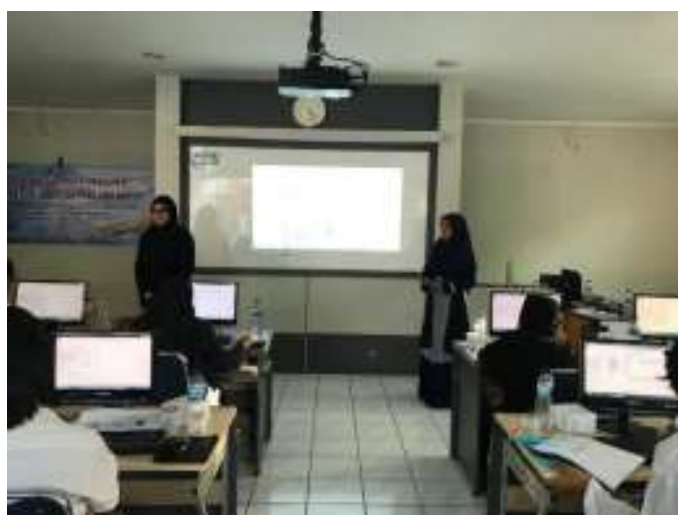

Gambar 2. Sambutan dari pihak PKBM Bina Bangsa Larangan

Pada Gambar 3 para siswa PKBM Bina Bangsa sedang mempraktikkan teori yang diberikan instruktur dan didampingi oleh asisten.

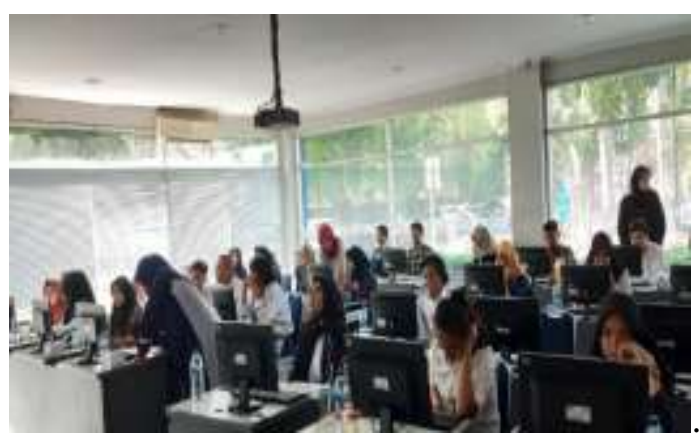

Gambar 3. Siswa PKBM sedang mempratikan teori yang disampaikan.

Pada gambar 4 merupakan contoh hasil pelatihan siswa

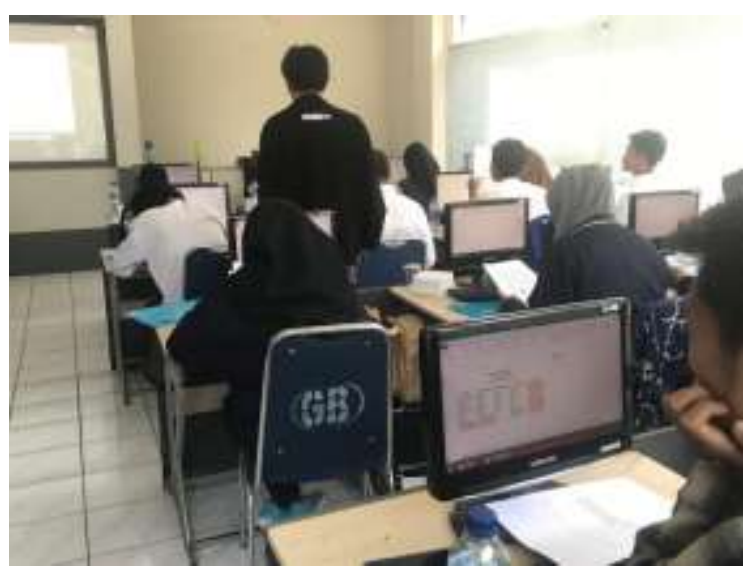

Gambar 4. contoh hasil pelatihan siswa.
Pada Gambar 5 setelah selesai pelatihan diadakan foto bersama siswa, pendamping PKBM Larangan dan Instuktur, Asisten dari Universitas Budi Luhur.

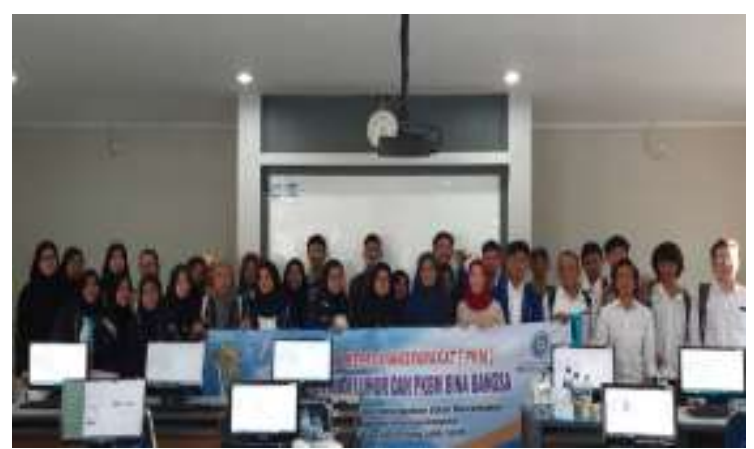

Gambar 5. Foto bersama setelah selesai pelatihan.

Pada kegiatan pengabdian masyarakat di PKBM Bina Bangsa terdapat beberapa siswa yang telah memiliki pengetahuan dasar komputer, tapi juga terdapat beberapa siswa yang memang sama sekali belum pernah menggunakan komputer sehingga perlu pendampingan kusus ketika pelaksanaan pelatihan.

Evaluasi hasil didapat dari nilai post test dan latihan yang dikerjakan siswa setelah kegiatan pelatihan. Siswa dinyatakan lulus/berhasil jika siswa mendapatkan score $>59$.

Komposisi Penilaian yaitu

a. Nilai < 59 maka D (Kurang).

b. Nilai 60-74 maka C (Cukup).

c. Nilai 75-84 maka B (Baik).

d. Nilai 85-100 maka A (Baik Sekali).

Hasil nilai post test siswa PKBM Bina Bangsa Larangan yang disajikan dalam bentuk grafik ditunjukan pada gambar 5, 6 dibawah ini:

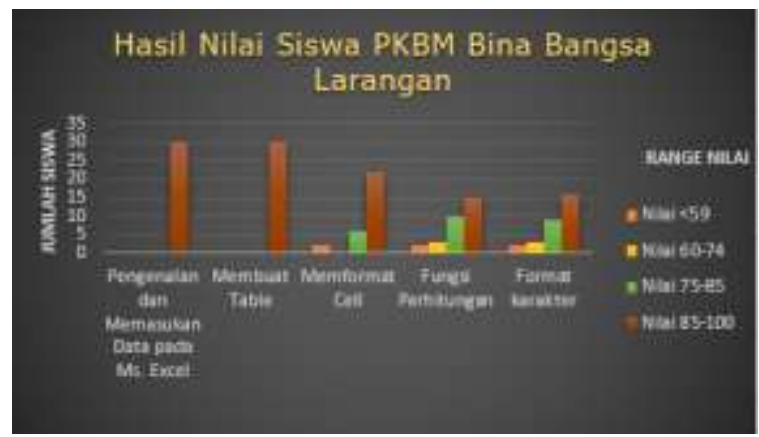

Gambar 6. Nilai siswa per materi 


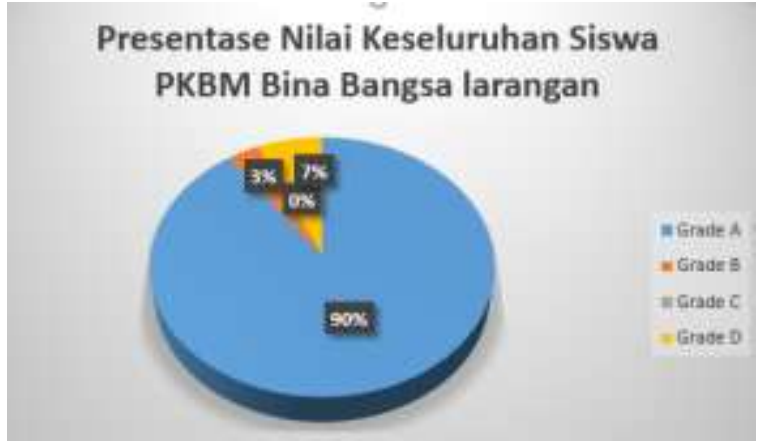

Gambar 7. Presentase nilai keseluruhan

Dari grafik di atas dapat disimpulkan bahwa nilai rata-rata siswa PKBM Bina Bangsa yang telah mengikuti pelatihan Microsoft Excel telah mampu mengerjakan latihan dengan mendapatkan nilai rata-rata " $\mathrm{A}$ ".

\section{SIMPULAN DAN SARAN}

Berdasarkan hasil dari kegiatan pelatihan pengabdian masyarakat dan pembahasan yang telah diuraikan sebelumnya, maka dapat disimpulkan bahwa:

a. Sebelum mengikuti training pengabdian masyarakat, siswa PKBM Bina Bangsa tidak memiliki kompetensi yang memadai dalam mengiperasikan aplikasi Microsoft Excel.

b. Telah dilaksanakan training pengabdian masyarakat untuk mengingkatkan kompetensi siswa PKBM Bina Bangsa, terutama dalam pengolahan data sederhana menggunakan aplikasi Microsoft Excel.

c. Setelah selesai mengikuti training, siswa PKBM Bina Bangsa mengikuti post test sederhana. Hasil dari test tersebut menunjukkan pengetahuan siswa akan pengolahan data sederhana dengan Microsoft Excel meningkat, dapat dilihat dari grafik yang menunjukan nilai rata-rata siswa mendapatkan nilai "A". Meski terdapat beberapa siswa yang mendapatkan nilai "D".
Saran yang diberikan perlu dilakukan pre test sebelum melakukan pelatihan agar mengetahui kemampuan siswa, tujuanya antara materi dan kemampuan siswa dapat sesuai/tepat.

\section{UCAPAN TERIMA KASIH}

Ucapan terima kasih disampaikan kepada Bapak Drs. Sutoro selaku ketua PKBM telah memberikan kesempatan bagi tim pengabdian masyarakat untuk berbagi ilmu dengan siswa yang ada di PKBM Bina Bangsa Larangan dan ucapan terimakasih untuk Universitas Budi Luhur yang telah mendanai kegiatan pengabdian masyarakat ini .

\section{DAFTAR PUSTAKA}

Hardjono, Raharjo, T. J., \& Suminar, T. (2016). Model Pemberdayaan Pusat Kegiatan Belajar Masyarakat Dalam Pengelolaan Program Pendidikan Kesetaraan Berbasis Life Skills Dan Kewirausahaan. Edukasi, 1(2).https://journal.unnes.ac.id/nju/inde. php/edukasi/article/view/955

Indonesia, P. R. (2005). Undang undang Republik Indonesia No. 14 tentang Guru dan Dosen.

Indonesia, P. R. (2012). Undang Undang RI Nomor 12 Tahun 2012 Tentang Pendidikan Tinggi.

Jalal, F., \& D, S. (2001). Reformasi Pendidikan dalam Konteks Otonomi Daerah. Yogyakarta: Adecitra Karya Nusa.

Suminar, U. (2007). Hubungan kemampuan manajerial, motivasi kerja, dan persepsi pengelola terhadap program pemberdayaan dengan mutu pelayanan pkbm di kabupaten garut. Jurnal Ilmiah VISI PTK-PNF, 2(1). 